From the National Veterinary Institute, Oslo, and the Department of Internal Medicine I, Division of Parasitology, Norwegian College of Veterinary Medicine, Oslo, Norway.

\title{
Elaphostrongylus Cervi Infection in Moose (Alces Alces). Prevalence and Pathological Changes in Relation to Age and Season
}

\author{
By Gudbrand Stuve
}

\begin{abstract}
Stuve, G.: Elaphostrongylus cervi infection in moose (Alces alces). Prevalence and pathological changes in relation to age and season. Acta vet. scand. 1987, 28, 157-164. - The prevalence of Elaphostrongylus cervi infection in 8-10-month-old moose calves shot in March/April in Southeastern Norway was studied. The prevalence was compared with the prevalence of infection in 4-6- and 16-18-monthold animals shot in September/October. The location of adult worms, the pathological changes which they caused within the central nervous system and their pathogenicity, were also studied. Examination of 54 8-10-month-old moose calves revealed that $46(85 \%)$ of the calves were infected with E. cervi. Thus a considerable proportion of the calves in the areas investigated obviously became infected with E. cervi during their first summer season. The prevalence of infection seemed to decline from the age of 8-10 months in spring till the age of 16-18 months in autumn. No difference in mean carcass weight was found between infected and non-infected calves of comparable age. Within the central nervous system adult E. cervi and associated pathological changes were found exclusively in the epidural space. The high prevalence of E. cervi infection, the insignificant differences in general condition between infected and non-infected calves and the epidural location of adult worms suggest, when considered together, that E. cervi infection in general is only moderately pathogenic in moose.

The lungworm Varestrongylus alces was found in 18 of 70 moose calves examined (26\%).
\end{abstract}

Protostrongylidae; Cervidae; epidemiology; Varestrongylus.

\section{Introduction}

The prevalence of Elaphostrongylus cervi Cameron, 1931 infection in moose (Alces alces) in Southern Norway in the autumn of 1983 was estimated to be $35 \%$ (Stuve 1986). The prevalence of infection among the yearlings (approximately 16-18 months old) was $67 \%$, among the calves (approximately 4-6 months old) $31 \%$ and among the adults ( $\geq$ $21 / 2$ years old) $21 \%$.

Experimental E. cervi infection has been re- ported in a captive moose calf by Lankester (1977). Clinical manifestation, gross lesions and location of adult worms were described. However, no scientific report has previously been published on the pathological changes associated with E. cervi infection in naturally infected, free-ranging moose.

The present paper reports and compares the prevalence of E. cervi infection in autumn and spring in moose calves from Southeastern Norway. The location of E. cervi 
within the central nervous system (CNS) and the associated pathological changes are described in relation to the age of the animals. Possible effects of the infection on the calves are discussed. The rate of faecal excretion of first-stage larvae (L1) is also presented.

In addition, a report is given on the prevalence of the specific lung nematode Varestrongylus alces Demidova \& Neumytsjeva, 1953 in the moose examined.

\section{Materials and methods \\ Materials}

Samples were collected in March/April 1984 and 1985 from 54 8-10-month-old moose calves, who were shot for research purposes in the four municipalities Åmot, Kongsvinger, Åsnes and Grue in Hedmark county. In addition, samples were collected during the hunting season in September/October 1984 from 14 4-6-month-old calves shot in Kongsvinger and in Gjøvik municipality in Oppland county. The nature of the samples from different calves varied somewhat as shown in Table 1. The sex, approximate age, general condition, carcass weight and any signs of neurological disorders observed in the animals concerned were recorded by the hunters. The material collected from all but 1 of the 8-10-monthold calves was stored at $-20^{\circ} \mathrm{C}$ from the day of slaughter until examination. The material from the other calves was examined shortly after slaughter.

Previously reported data on the prevalence of E. cervi infection in 4-6- and 16-18month-old animals and data on carcass weight and faecal larval output in 4-6month-old calves obtained from Åmot, Kongsvinger and Gjøvik in 1983 (Stuve 1986) were included for comparative purposes.
Table 1. Material collected from 14 4-6-monthold moose calves (in the autumn of 1984) and from 54 8-10-month-old calves (in the spring of 1984 and 1985).

\begin{tabular}{|c|c|c|}
\hline \multirow[b]{2}{*}{ Material } & \multicolumn{2}{|c|}{ No. of animals } \\
\hline & $\begin{array}{l}4-6 \text { months } \\
\text { old }\end{array}$ & $\begin{array}{l}8-10 \text { months } \\
\text { old }\end{array}$ \\
\hline $\begin{array}{l}\text { Head, carcass }{ }^{1}, \\
\text { lungs and faeces }\end{array}$ & & 1 \\
\hline $\begin{array}{l}\text { Vertebral columna }{ }^{2} \text {, } \\
\text { lungs and faeces }\end{array}$ & & 42 \\
\hline Spinal cord and lungs & 10 & \\
\hline Lungs and faeces & & 11 \\
\hline Lungs & 4 & \\
\hline
\end{tabular}

\section{Examination of the CNS}

The entire spinal cord and brain were carefully removed from one 8-10-month-old moose calf and the portion of the spinal cord extending from the 5 th cervical to the 6 th thoracic vertebra was removed from each of 42 8-10-month-old calves (Table 1). The spinal cord together with the meninges, the spinal nerve roots and the surrounding fat and loose connective tissue were examined grossly and with a dissecting microscope for nematodes and pathological changes and then fixed in $10 \%$ neutral buffered formalin. The spinal cord with meninges, spinal nerve roots and surrounding fat and loose connective tissue from each of 10 4-6-monthold calves (Table 1), were removed from the vertebral canal on the day of slaughter, and examined grossly for the presence of nematodes and pathological changes before being fixed in $10 \%$ neutral buffered formalin. The nematodes were removed and fixed in $70 \%$ alcohol for light microscopic identification. 
Six specimens from the single formalin-fixed brain and 6-10 specimens from each formalin-fixed spinal cord were processed routinely and embedded in paraffin. Sections at 5-7 $\mu \mathrm{m}$ were stained with hematoxylin and eosin (HE) and selected sections with Prussian blue.

\section{Examination of the carcass}

The carcass of the single $8-10$-months old calf of which the entire CNS was examined (Table 1) was dissected soon after slaughter and the muscles were examined grossly and with a dissecting microscope for the presence of nematodes and pathological changes.

\section{Examination of lungs and faeces}

The lungs and faecal samples (Table 1) were examined as described by Stuve (1986). Briefly, the lungs were examined grossly and histologically and, like the faecal samples, subjected to baermannisation. In addition, bronchial mucus were examined by light microscopy for the occurrence of first-stage larvae of $\mathrm{E}$. cervi.

\section{Statistics}

The F- and Chi-square tests were used to test for significant differences between different categories of animals (infected, noninfected, different age groups). $\mathrm{P}$ values of $<0.01$ were considered to be statistically significant.

\section{Results}

No obvious symptoms of neurological disorders were recorded in any of the animals included in this study.

Table 2 shows the prevalence of E. cervi infection in moose calves in relation to age and season. Among the 4-6-month-old calves the prevalence in the autumn of 1983 did not differ significantly from that in the autumn of 1984 . Nor was there any significant difference in the prevalence among the 8-10-month-old calves between the spring of 1984 and 1985.

Table 3 shows the mean carcass weight of infected and non-infected calves in relation to age. Neither among 4-6-month-old calves nor among $8-10$-month-old calves were

Table 2. Prevalence of E.cervi infection in moose calves in autumn and spring in the different areas studied.

\begin{tabular}{|c|c|c|c|c|c|c|}
\hline \multirow[b]{3}{*}{ Season } & \multicolumn{6}{|c|}{ Age of calves } \\
\hline & \multicolumn{2}{|c|}{ 4-6 months } & \multicolumn{2}{|c|}{$8-10$ months } & \multicolumn{2}{|c|}{$16-18$ months } \\
\hline & $\begin{array}{l}\text { No. ex- } \\
\text { amined }\end{array}$ & $\begin{array}{l}\text { Preval- } \\
\text { ence }(\%)\end{array}$ & $\begin{array}{l}\text { No. ex- } \\
\text { amined }\end{array}$ & $\begin{array}{l}\text { Preval- } \\
\text { ence }(\%)\end{array}$ & $\begin{array}{l}\text { No. ex- } \\
\text { amined }\end{array}$ & $\begin{array}{l}\text { Preval- } \\
\text { ence }(\%)\end{array}$ \\
\hline Autumn 1983 & $82^{1}$ & 37 & & & $141^{1}$ & 73 \\
\hline Spring 1984 & & & $25^{2}$ & 88 & & \\
\hline Autumn 1984 & $14^{3}$ & 57 & & & & \\
\hline Spring 1985 & & & $29^{2}$ & 83 & & \\
\hline
\end{tabular}


Table 3. Mean carcass weight $(\mathrm{kg})$ in infected and non-infected moose calves in relation to age.

\begin{tabular}{lcccccccc}
\hline & \multicolumn{3}{c}{ Infected calves } & & \multicolumn{3}{c}{ Non-infected calves } \\
\cline { 2 - 3 } Age (in months) & $\begin{array}{c}\text { No. of } \\
\text { animals }\end{array}$ & $\begin{array}{c}\text { Mean } \\
\text { weight }\end{array}$ & SD & & $\begin{array}{c}\text { No. of } \\
\text { animals }\end{array}$ & $\begin{array}{c}\text { Mean } \\
\text { weight }\end{array}$ & SD \\
\hline $4-6^{1}$ & 23 & 72 & 4.8 & & 58 & 69 & 4.1 \\
$8-10$ & 48 & 68 & 12.9 & & 8 & 69 & 16.9 \\
\hline
\end{tabular}

${ }^{1}$ Data from Kongsvinger, Åmot and Gjøvik (Stuve 1986).

Table 4. The mean larval output per gram of faeces (LPG) in moose calves in autumn and spring.

\begin{tabular}{llcrr}
\hline Season & Age (in months) & $\begin{array}{c}\text { No. of } \\
\text { animals }\end{array}$ & $\begin{array}{r}\text { Mean } \\
\text { LPG }\end{array}$ & SD \\
\hline Autumn 1983 & $4-6^{1}$ & 21 & 13 & 23 \\
Spring 1984-85 & $8-10$ & 45 & 211 & 190 \\
\hline
\end{tabular}

${ }^{1}$ Data from Kongsvinger, Åmot and Gjøvik (Stuve 1986).

there any significant differences in carcass weights between infected and non-infected animals.

Table 4 shows the mean faecal larval counts in moose calves in relation to age and season.

\section{Pathological findings in 8-10-months old calves}

In all the 8-10-month-old calves in which the vertebral columna was examined there was moderate to extensive serous atrophy of the adipose tissue within the epidural space. Eight adult E. cervi were found in the epidural space between the last cervical and the 5 th thoracic vertebra in the single 8-10month-old calf of which the entire CNS and carcass was examined. Moreover, 2 adult E. cervi were found in the epimysium between Musculus pectineus and M. adductor in the left hind leg of this calf.

Twenty-one of the 42 8-10-month-old calves in which a portion of the vertebral columna was examined (Table 1), were found to harbour adult E. cervi worms (range 1-9 worms; average 4 worms). In 34 of the $8-10$ month-old calves examined gross lesions, most notably oedema, small haemorrhages and yellow-brownish discolouration, were observed in the epidural space. Such lesions were present in all the calves found to be harbouring adult E.cervi in the epidural space and also in 12 calves from which no adult worms were recovered.

Histological examination of the epidural connective tissue from these 34 calves revealed infiltrations and focal accumulations of polymorphonuclear and mononuclear cells. Other pathological changes included oedema, small haemorrhages, eosinophilic vasculitis, trombotic occlusions of small blood and lymph vessels and focal granulomas containing eggs and/or larvae of E. cervi and foreign body giant cells. Numerous macrophages containing hemosiderin were observed in the epidural space. Lesions were not found in the leptomeninges or in the neural parenchyma. 
Eggs and larvae of E. cervi and associated histopathological changes with mild bronchopneumonia were observed in the lungs of 46 of the 54 8-10-month-old calves examined $(85 \%)$. All calves harbouring worms and/or showing associated lesions in the epidural space also harboured eggs and larvae in the lungs. In addition, eggs and larvae of E. cervi were found in the lungs of 2 calves in which neither worms nor lesions were observed within the portion of CNS examined. In these 2 calves the adult nematodes might have been located in the segments of the vertebral columna that were not examined or in the musculature. Ten of the 11 calves in which only lungs and faeces were examined (Table 1), also had eggs and larvae of E. cervi in the lungs.

\section{Pathological findings in 4-6-month-old calves}

In each of 4 4-6-month-old calves 1 adult E. cervi was found in the epidural space of the lumbar part of the vertebral canal. However, neither in these 4 calves nor in the 6 other 4-6-month-old calves, in which the spinal cord was examined, were any gross lesions observed within the CNS. Moreover, all the calves had well-developed epidural fat deposits. The histological examination, on the other hand, revealed moderate infiltration with polymorphonuclear and mononuclear cells in the lumbar and sacral portion of the epidural space of all 4 calves from which worms were recovered. Focal aggregations of leukocytes and scattered histiocytes containing hemosiderin were also seen.

Disseminated eggs and larvae of E. cervi with associated mild bronchopneumonia were observed in 8 of the 14 lungs (57\%) from 4-6-month-old calves. The 4 calves in which adult E. cervi were present in the epi- dural space all had eggs and larvae of the worms in the lungs.

Prevalence of Varestrongylus alces infection Infection with $\mathrm{V}$. alces was found in 18 out of 70 lungs ( $26 \%$ ) examined. Characteristic greyish, well-defined brood nodules containing numerous eggs and first-stage larvae of V. alces were found in the lungs of infected animals. The predilection site of the nodules seemed to be the dorsal portion of the diaphragmatic lobes. Adult worms were isolated from brood nodules in 10 of the 18 infected animals. Histological examination showed a localized bronchopneumonia surrounding the brood nodules.

\section{Discussion}

The prevalence of E. cervi infection in 8-10month-old moose calves in the present study (Table 2) indicates that a considerable proportion of the calves in the areas under study become infected during their first summer season, whereas the prevalence of infection seems to decline again during the second summer. Previously, it has been shown that the prevalence of E. cervi infection declines further with increasing age in moose more than $11 / 2$ years old, presumably due to acquired immunity (Stuve 1986). Yearlings and adult moose will probably ingest more snails than the calves and thus be more exposed to infective E. cervi L3. Nevertheless, patent infections with E. cervi seem to occur most often in calves that have had little or no previous exposure to E. cervi, and the level of immunity or the age of the animals per se, rather than the rate of infection, thus seems to determine whether or not a given animal will harbour adult $\mathrm{E}$. cervi.

In 1983 the estimated mean prevalence of E. cervi infection in moose, irrespective of 
age, in the areas represented in this study was only slightly higher than the mean prevalence $(35 \%)$ in Southern Norway as a whole (Stuve 1986). Considered together with the high prevalence estimated in 8-10month-old calves in the present study $(85 \%)$, it may be concluded that the Southern Norwegian moose population in general is highly exposed to E. cervi.

In Norway moose may become infected with E. cervi during the summer season between May and November, i.e. during the period when the snail intermediate host is available. However, the prepatent period of E. cervi is 2-4 months (Mitskevich 1964, Lankester 1977) and animals infected late in the summer may therefore not harbour egg-laying female worms until late winter. A comparison of the prevalence of E. cervi eggs and L1 among 4-6 and 8-10-monthold calves indicates that less than half the number of calves infected during the first summer season have a patent infection by September/October. The prevalence of E. cervi infection in 4-6-month-old moose calves in 1983 seems, therefore, to have been underestimated by Stuve (1986).

At present most authors regard E. panticola Lubimow, 1945 and E. rangiferi Mitskevich, 1958 to be identical with E. cervi (Pryadko \& Boev 1971, Kutzer \& Prosl 1975, Pryadko 1976, Lankester \& Northcott 1979). The difference in the location of worms within the CNS between moose, as reported in the present paper, and other cervids, e.g. red deer and reindeer in which the worms are normally located within the leptomeninges ( $R o$ nèus \& Nordkvist 1962, Kutzer \& Prosl 1975), may be due to differences in the anatomy of the dura mater between the different species of cervids. The dura mater in moose is considerably thicker and more solid than in both red deer and reindeer (personal observations). The solid dura mater in moose may prevent the worms from entering the subdural space and the leptomeninges.

The location of E. cervi within the epidural space of the CNS described in the present paper corresponds well with the sites reported by Holt (1982). On the other hand, Steen \& Morner (1985) found worms within the leptomeninges, and Lankester (1977) reported that E. cervi were located not only within the leptomeninges but also in the brain ventricles and in the nervous tissue of the spinal cord in experimentally infected moose. These differences in the location of the worms within the CNS in moose may indicate that different strains of a single species, or even different species within the genus Elaphostrongylus, occur in moose. A renewed taxonomic evaluation of the genus may help to clarify the situation.

The lumbar and sacral location of nematodes and associated pathological changes in 4-6-month-old calves compared with the location throughout the epidural space caudally to the 5 th cervical vertebra in 8-10month-old calves, may indicate that the parasites enter the caudal portion of the vertebral canal and migrate cranially. Moreover, the absence of adult E. cervi from the epidural space in animals showing characteristic pathological changes at this site, may indicate that the adult worms also migrate out of the vertebral canal.

Moose seem to have the same seasonal pattern in larval output with high counts in winter and spring and low counts in summer and autumn, as reported in both red deer and reindeer (Prosl \& Kutzer 1980, Wissler \& Halvorsen 1976).

Stuve (1986) considered the pathogenicity of E. cervi in moose to be moderate. Holt (1982), on the other hand, reported increased mortality during winter, especially in moose calves in certain areas, probably as a result of elaphostrongylosis, and he assumed 
that calves were more prone to be adversely affected by the infection than adult moose. Steen \& Morner (1985) also reported mortality in moose as a result of elaphostrongylosis, and Lankester (1977) showed that E. cervi caused severe neurological disorders in moose. The insignificant difference in carcass weight between infected and non-infected moose calves and the high prevalence coupled with an apparenly low mortality found in the present study, indicate that E. cervi in general has only a moderate pathogenic effect in young moose. The fact that both infected and non-infected animals showed an impairment of their general condition during winter, including serous atrophy of the epidural adipose tissue and a failure to gain weight, suggests that the climate and the availability of feed during winter may have a more significant influence on the condition of the moose calves than the infection with E. cervi. However, the ability of moose infected with E.cervi to survive harsh winters with deep snow and shortage of feed will probably be reduced.

Nilsson (1971) found V. alces, referred to as Bicaulus alces, in $42 \%$ of moose examined in Sweden, whereas Stuve (1986) reported a mean prevalence of $8 \%$ in Southern Norwegian moose. Judged together with the prevalence found in this study ( $26 \%)$, it seems that V.alces is a common parasite in the Scandinavian moose population.

\section{Acknowledgement}

This study was financially supported by the Norwegian Agricultural Research Council. I thank Professor O. Helle and Dr. G. Holt for essential help and guidance, Dr. B. Gjerde for linguistic advice and A. Stovner and A. M. Næshagen for technical assistance. Thanks are also due to local wildlife authorities and hunters in the municipalities included in this investigation.

\section{References}

Cameron TVM: On two new species of nematodes from Scottish red deer. J. Helminthol. 1931, 9, 213-216.

Demidova $N V$, Naumytsjeva MI: A new nematode Varestrongylus alces sp. nov. in moose. Moskovskij Pushno-Mekhovoj Institut. Trudy. 1953, 4, 303-306. (In Russian).

Holt $G$ : Påvisning av elaphostrongylose hos elg i Sør-Norge gir grunn til en viss engstelse. (Demonstration of elaphostrongylosis in moose in South-Norway gives reason for some anxiety). Jakt, fiske og friluftsliv. 1982, 9, 33-34.

Kutzer E, Prosl H: Zur Kenntnis von Elaphostrongylus cervi Cameron, 1931. I. Morphologie und Diagnose. (Contribution to the knowledge of Elaphostrongylus cervi Cameron, 1931. I. Morphology and diagnosis). Wien tierärztl. M.schr. 1975, 62, 258-266.

Lankester $M V$ : Neurological disorders in moose caused by Elaphostrongylus cervi Cameron, 1931 from caribou. Proc. 13th North American Moose Conference and Workshop. Jasper, Alberta 1977, 177-190.

Lankester $M V$, Northcott TH: Elaphostrongylus cervi Cameron, 1931 (Nematoda: Metastrongyloidea) in caribou (Rangifer tarandus caribou) of Newfoundland. Can. J. Zool. 1979, 57, 1384-1392.

Lubimov MP: New worm disease of the brain of deer with unossified antlers. Sbornik nauchoissledovatel'skikh rabot. Laboratory pantovogo olenvodestva Ministerstva sovkhozov SSSR 1945, 1, 225-232. (In Russian).

Mitskevich WJ: Studies on the life cycle of the nematode Elaphostrongylus rangiferi sp. nov. in reindeer. Dokl. Akad.nauk. SSR 1958, 118, 253-255.

Mitskevich WJ: The development cycle of Elaphostrongylus rangiferi Miz. 1958. Sbornik, "Parazity sel skokhoziastv. Zhivotnykh Kazakhstana« 1964, 3, 49-60. (In Russian).

Nilsson $O$ : The interrelationships of endo-parasites in wild cervids (Capreolus capreolus L. and Alces alces L.) and domestic ruminants in Sweden. Acta vet. scand. 1971, 12, 36-68. 
Prosl H, Kutzer E: Zur Biologie und Bekämpfung von Elaphostrongylus cervi. (Biology and control of Elaphostrongylus cervi). Z. Jagdwiss. 1980, 26, 198-207.

Pryadko EI: Helminths of cervids. Alma Ata, USSR. Izdatel'stvo Nauka Kazakhskoi 1976. 1-224. (In Russian).

Pryadko EI, Boev SN: Systematics, phylogeny and evolution of Elaphostrongylinea - nematodes of deer. Izv. Akad. Nauk. Kaz. SSSR. Ser. Zool. 1971, 3, 74-85. (In Russian).

Ronèus $O$, Nordkvist $M$ : Cerebrospinal and muscular nematodiasis (Elaphostrongylus rangiferi) in Swedish reindeer. Acta vet. scand. 1962, 3, 201-225.

Steen, $M$, Morner $T$ : »Hjärnmask « - en ny allvarlig viltsjukdom. (»Brainworm « - a new serious disease of wild game). Svensk Jakt 1985, 7/8, 601-603.

Stuve G: The prevalence of Elaphostrongylus cervi infection in moose (Alces alces) in Southern Norway. Acta vet. scand. 1986, 27, 397409.

Wissler $K$, Halvorsen $O$ : Infection of reindeer with Elaphostrongylus rangiferi (Nematoda: Metastrongyloidea) in relation to age and season. Nor. J. Zool. 1976, 24, 462-463.

\section{Sammendrag}

Elaphostrongylus cervi-infeksjon hos elg (Alces alces). Prevalens og patologiske forandringer $i$ forhold til alder og årstid.

Prevalensen av Elaphostrongylus cervi-infeksjon ble undersøkt hos 8-10 måneder gamle elgkalver som ble avlivet til forskjellige forskningsformål i mars/april 1984 og 85 i Hedmark fylke. Den estimerte prevalensen ble sammenlignet med prevalensen hos 4-6 og 16-18 måneder gamle dyr avlivet under ordinær jakt i september/oktober 1983 og $84 \mathrm{i}$ de samme områder. Lokalisasjonen av kjønnsmodne ormer i sentralnervesystemet, og de patologiske forandringene forårsaket av disse, ble undersøkt hos 4-6 og 8-10 måneder gamle kalver og patogeniteten ble vurdert. En vesentlig del av elgkalvene i de aktuelle områdene så ut til å bli infisert med E. cervi i løpet av sin første sommer. Av 54 undersøkte 8-10 måneder gamle kalver var $85 \%$ infisert med E. cervi. Videre så det ut til at prevalensen avtok med stigende alder. Det var ingen forskjell i gjennomsnittlig slaktevekt mellom infiserte og ikke infiserte kalver i samme aldersgruppe. Kjønnsmodne E. cervi og patologiske forandringer forårsaket av disse ble påvist $\mathrm{i}$ muskulaturen og epiduralt $i$ sentralnervesystemet hos infiserte kalver. Høy prevalens uten iøynefallende kliniske symptomer, tilnærmelsesvis like slaktevekter hos infiserte og ikke-infiserte kalver og epidural lokalisasjonen av parasittene $\mathrm{i}$ CNS indikerer at E. cervi er moderat patogen for elgkalver.

Lungeormen Varestrongylus alces ble påvist hos $26 \%$ av de undersøkte elgkalvene.

(Received November 13, 1986).

Reprints may be requested from: G. Stuve, National Veterinary Institute, P. O. Box 8156 Dep., N-0033 Oslo 1, Norway. 